\title{
Scenarios for the evolution of life on Mars
}

\author{
Dirk Schulze-Makuch, ${ }^{1}$ Louis N. Irwin, ${ }^{2}$ Jere H. Lipps, ${ }^{3}$ David LeMone, ${ }^{4}$ \\ James M. Dohm, ${ }^{5}$ and Alberto G. Fairén ${ }^{6}$ \\ Received 10 March 2005; revised 2 August 2005; accepted 7 September 2005; published 22 November 2005.
}

Citation: Schulze-Makuch, D., L. N. Irwin, J. H. Lipps, D. LeMone, J. M. Dohm, and A. G. Fairén (2005), Scenarios for the evolution of life on Mars, J. Geophys. Res., 110, E12S23, doi:10.1029/2005JE002430.

\section{Introduction and Strategy}

[2] Life as we know it requires a flow of energy through a system of complex chemical interactions occurring in a bounded aqueous environment (see Schulze-Makuch et al. [2002] for a recent discussion). Energy, complex chemistry, and water were available on both Earth and Mars in their early histories. Since environmental conditions on both planets were very similar initially, the origin of life may have occurred separately on both planets. Alternatively, Martian and Earth organisms may have had a common origin, with interplanetary transfer of life among the terrestrial inner planets [Horneck et al., 1994; Davies, 1996; Nicholson et al., 2000]. Whether life originated on Earth or was transported here from another place, this single example shows the origin or colonization of life to be achievable

\footnotetext{
${ }^{1}$ Department of Geology, Washington State University, Pullman, Washington, USA.

${ }^{2}$ Department of Biological Sciences, University of Texas at El Paso, El Paso, Texas, USA.

${ }^{3}$ Department of Integrative Biology and Museum of Paleontology, University of California at Berkeley, Berkeley, California, USA

${ }^{4}$ Department of Geological Sciences, University of Texas at El Paso, El Paso, Texas, USA.

${ }^{5}$ Department of Hydrology and Water Resources, University of Arizona, Tucson, Arizona, USA.

${ }^{6}$ Centro de Biología Molecular, Universidad Autónoma de Madrid, Madrid, Spain.
}

Copyright 2005 by the American Geophysical Union. 0148-0227/05/2005JE002430\$09.00 within a few hundred million years of the opportunity for it to happen [de Duve, 1995; Lahav, 1999], or even as little as a few thousand years [Lazcano and Miller, 1994]. Since life arose relatively quickly under Earth conditions, it may have also arisen on Mars very quickly. Once established, however, life on Earth and Mars would necessarily have followed different evolutionary trajectories, because the environmental history of Mars and Earth diverged drastically after the first several hundred million years [Baker et $a l ., 2002]$. By reviewing the known history of life on Earth, and comparing the environmental and climatological histories of Earth with those hypothesized for Mars, we will postulate two plausible trajectories and a third less likely possibility for the evolution of life on Mars. In this paper, for Earth we use the geologic timescale from Gradstein et al. [2004]. For Mars, the geochronology is derived from stratigraphic and crosscutting relationships among materials and structures, as well as impact crater statistics [e.g., Scott and Tanaka, 1986; Greeley and Guest, 1987]. On Mars, the Noachian Period, named after Noachis Terra, is the earliest time period, followed by the Hesperian Period (named after Hesperia Planum) and the Amazonian Period (named after Amazonis Planitia; see also Figure 1).

\section{History of Life on Earth}

\subsection{Hadean (Early Eoarchaean; Prior to $4 \mathrm{Ga}$ )}

[3] Not much is known of this earliest time on Earth, other than what can be inferred from extraterrestrial bodies 


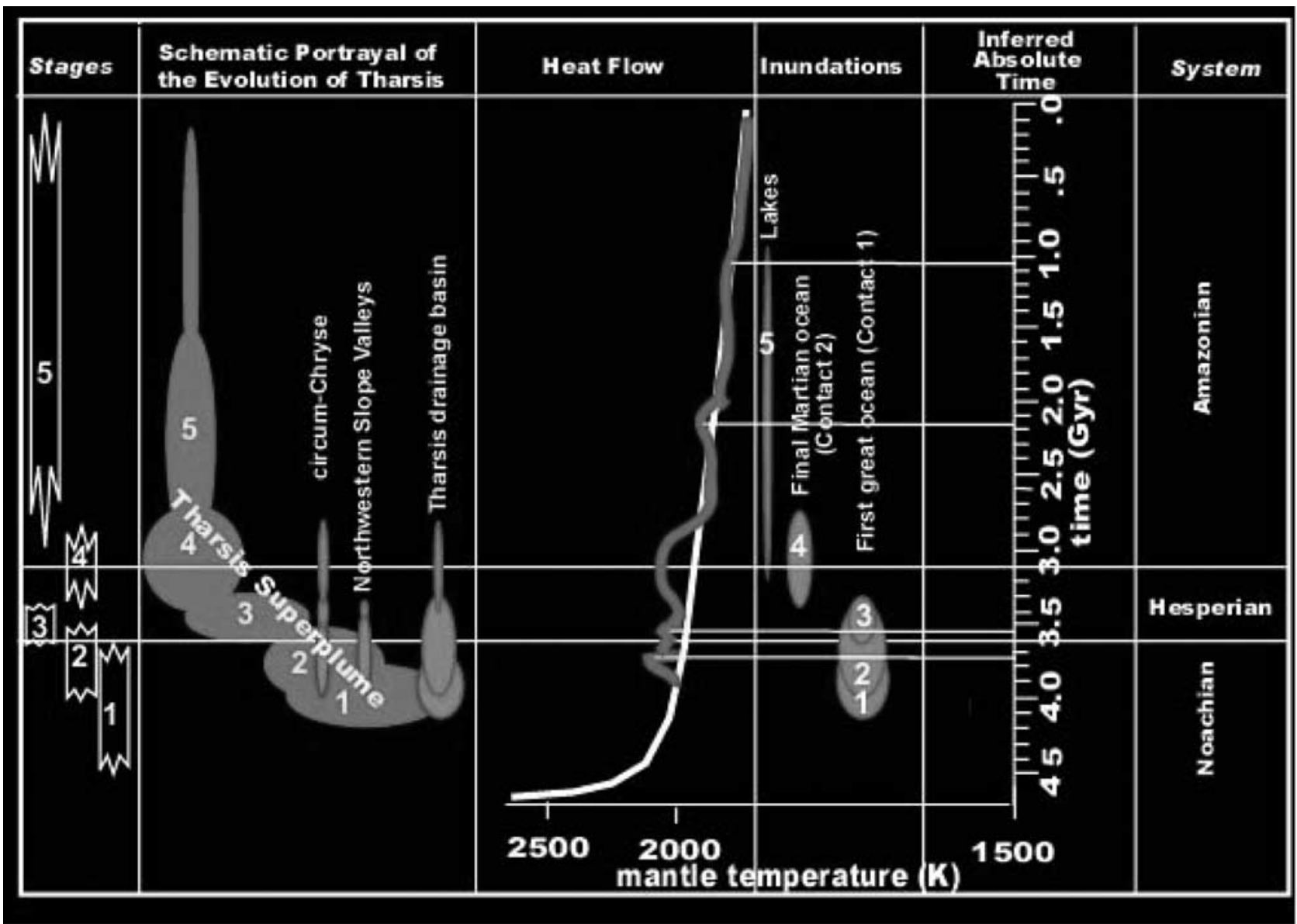

Figure 1. Chart comparing the evolutional stages of geologic activity in the Tharsis Magmatic Complex [Dohm et al., 2001a], which includes circum-Chryse, Northwestern Slope Valleys [Dohm et al., 2001c], and Tharsis drainage basin/aquifer system [Dohm et al., 2001a] with (1) heat flow; note the maximum effective heat flow to lithosphere in the Early into Middle Noachian and nonsteady state decline in subjective heat flow (dark gray line) compared to proposed steady state decline in mantle temperature with time (white line [Schubert et al., 1992]), following the Middle Noachian based on published geologic information [e.g., Dohm et al., 2001a; Baker et al., 2002; Fairén et al., 2003], (2) hypothesized Tharsis-triggered inundations in the northern plains ranging from oceans to lakes [Fairén et al., 2003], (3) inferred absolute time [Hartmann, 2001], and (4) system information of Scott and Tanaka [1986]. Sizes of solid areas are roughly proportional to degree of exposed activity.

that fell to Earth, cratering records on the Moon and other planets, and zircon grains incorporated into younger rocks. The zircons have yielded ages ranging from 4.3-4.4 Ga indicating the presence of granitic rock at that time. The magma producing the zircons encountered surface water [Kramers, 2001]. On the basis of crater counts on nearby bodies in the Solar System, Earth is thought to have been subjected to intense bombardment by bolides relatively early in its history. Growing evidence indicates that the period of Late Heavy Bombardment (LHB) was a catastrophic bombardment event by asteroids and meteors from the main asteroid belt [Strom et al., 2005] once Jupiter was set in place. This period was from $\sim 10 \mathrm{Ma}$ to $\sim 150 \mathrm{Ma}$ in duration and began approximately $3.9 \mathrm{Ga}$ ago [Gomes et al., 2005; Tsiganis et al., 2005]. The impacts may have been sufficient to impede the accumulation of water or oceans and the sustained development of life [Nisbet and Sleep, 2001]. Within a billion years, the bombardment slowed and decreased in intensity as the bolides became smaller and fewer. These asteroids and meteors, as well as comets, likely brought to Earth's surface sufficient amounts of organic material for life to start [Anders, 1989; Chyba et al., 1990]. The organic molecules served as the foundation of life itself, and were utilized as trophic resources for the newly evolving cellular organisms. Thus life had what was needed to form and survive early in Earth's history.

\subsection{Archean (4.0 to 2.5 Ga)}

[4] Early Archean metasedimentary rocks make up a small percentage of exposures on the continents today, but the oceans and the life at those times are essentially unknown [Lowe, 1992; Knoll, 2003]. While supposed bacterial fossils were described from 3.5 Ga old rocks [Schopf, 1993; Schopf and Packer, 1987], they have been reinterpreted as non-biologic kerogen artifacts [Brasier et $a l ., 2002]$. The presence of life, nevertheless, is indicated by isotopic evidence [Rosing, 1999] and by other fossil occurrences at about this same time or slightly later (see Schopf 
[1992] for a summary). The relatively early appearance of life on Earth provides empirical support for the theoretical expectation that given the proper materials, appropriate physical conditions, and a flow of energy, that matter will form itself inevitably into complex, self-organizing systems [Goodwin, 1994; Kauffman, 1995; Morowitz, 1968].

[5] Archean oceans contained little oxygen and abundant iron [Anbar and Knoll, 2002; Knoll, 2003]. Organisms present in those oceans were bacteria, probably archaea and eventually early eukaryotes [Brocks et al., 1999; Summons et al., 1999], likely both benthic and planktic. Some molecular phylogenies suggest an early divergence of eukaryotes [Gu, 1997; Hedges et al., 2001] leading by definition to ancestral protists, but this is an indirect conclusion subject to alternative interpretations [Katz, 1999]. Benthic trophic structures were likely confined to aggregations of films and mats composed of cyanobacteria and other bacteria, some of which formed stromatolites and laminated sedimentary rocks [Simonson and Carney, 1999; Nisbet and Sleep, 2001].

[6] The occurrence of banded iron formations (BIFs) from 3.8-1.8 Ga suggests deep oceans with high concentrations of ferrous iron during this time as a result of intense submarine magmatic and hydrothermal activity [Holland, 1973; Vargas et al., 1998]. BIFs may have formed from exclusively abiotic processes (photochemical oxidation of iron and continental weathering of iron minerals), microbial iron metabolism (anaerobic respiration of iron and iron as reduced power for $\mathrm{CO}_{2}$ assimilation), or microbial metabolic subproduct interactions (iron oxidation produced by oxygen released by cyanobacteria-related microorganisms). Thus BIFs may imply the existence of some type of microbial consortium in the Archean oceans. In this sense, high concentrations of soluble iron would have promoted the development of iron-oxidizing bacteria operating in the absence of oxygen [Gómez et al., 2004].

[7] Both benthic and pelagic prokaryotic ecosystems were probably widely distributed, at least in shallow open waters. Both of these ecosystems would likely have been functionally much simpler than later ones, as they surely lacked larger or more complex organisms. Both of these systems likely originated in benthic and in shallow waters, although they may have arisen at hydrothermal vents, because molecular phylogenies suggest that thermophilic bacteria and archaeans are basal to other extant groups [Reysenbach and Shock, 2002]. This scenario, however, has been seriously questioned on several grounds [Bada and Lazcano, 2002; Brochier and Philippe, 2002]. The earliest ecosystems probably did not have particularly unusual kinds of trophic interactions; they were likely limited and lacked oxygenic photoautotrophs [Nisbet and Sleep, 2001]. These benthic and pelagic ecosystems were also probably widely distributed in Earth's seas, at least in shallow waters.

[8] Pelagic realms of the Archean must have rather quickly evolved a prokaryotic biota. Prokaryotic trophic interactions would have been less complex than modern ones, and their diversity was probably lower, primarily due to limited sources of organic debris and the absence of larger plankton. Nevertheless, this pelagic system would have been fueled by organic matter from the prokaryotes themselves, or from other ecosystems elsewhere on Earth, and from viruses, co-occurring species, and the continued input of organic compounds from meteorites.

[9] After their initial evolution, prokaryotes probably soon radiated into most benthic marine habitats. While the record reveals only sparse prokaryotic fossils, it likely represents very few of the possible Archean environments. Finally, eukaryotic molecular biomarkers have been reported from the Late Archean at 2.7 Ga [Brocks et al., 1999], suggesting that eukaryotes were becoming important components of marine ecosystems.

[10] The process of photosynthesis has been critical to the further development of life on Earth. As photosynthesis evolved, it increased potential carbon fixation to orders of magnitude greater than that available from redox reactions [Des Marais, 2000]. Most critical was the ability of oxygenic photosynthetic bacteria to capture hydrogen for organic biosynthesis as the result of the process of photochemical disassociation of water. The photosynthetic process further filled the global oxygen sinks (as expressed, e.g., in Archean banded iron formations, Proteozoic red beds in euxinic oceans, and Precambrian pyrite-rich conglomerates in oxygenated oceans), and the eventual development of a terrestrial atmosphere containing oxygen. With the availability of atmospheric oxygen, the transition accelerated from a dominantly anaerobic biota to the more evolutionarily-plastic aerobic organism-dominated biota. While these ideas are logical, evidence for photosynthetic organisms is not secure, and the Archean remains biologically enigmatic. Life appears to have been present throughout the Eon, but its composition, trophic organization, and evolution cannot be deciphered. This severely constrains comparisons to the evolution of life on Mars, as Hadean (Eoarchean) -Archean terrestrial and aquatic environments are likely to be most similar to those of the Noachian Period of Mars. The subsequent evolution of life on both planets must have been dramatically different.

\subsection{Proterozoic (2.5 to $0.542 \mathrm{Ga})$}

[11] During the nearly two billion years of the Proterozoic, ecosystems evolved from simple types dominated by prokaryotes to those that were the immediate precursors of modern marine types. These included large metazoans and abundant larger primary producers in the benthos and a poorly preserved, but likely complex, group of plankton (Table 1) [Lipps and Culver, 2002]. These ecosystems changed over time as newly evolved organisms appeared and became integrated into these systems. The fossil record of the Paleoproterozoic and Mesoproterozoic is still poorly known, although the few fossils indicate that protists had become important parts of the benthic and pelagic ecosystems between 1.5-1.2 Ga [Vidal and Moczydlowska-Vidal, 1997; Javaux et al., 2001; Knoll, 2003]. Global events in the Proterozoic had significant impacts on marine ecosystems. These include a poorly known Snowball Earth I, an extensive period of glaciation at about $2.4 \mathrm{Ga}$ [Kirschvink et al., 2000], and an increase in atmospheric oxygen to about $15 \%$ of the present level between 2.2 and $1.8 \mathrm{Ga}$ [Holland, 1984; Farquhar et al., 2000; Bekker et al., 2004; Rouxel et al., 2005], perhaps promoting protist diversification and occupation of more habitats. The first protists fossils are cysts of planktic algae, known as acritarchs, which occur in rocks as old as $1.8 \mathrm{Ga}$ [Vidal and Moczydlowska-Vidal, 
Table 1. Chief Fossilizable Life-Forms on Earth and Their Trophic Functions and Geologic Age Based on Fossils ${ }^{\mathrm{a}}$

\begin{tabular}{|c|c|c|c|}
\hline Organisms & Habitat & Function & Age Range \\
\hline Heterotrophic bacteria & all & consumers & Archean-Recent \\
\hline $\begin{array}{l}\text { Autotrophic bacteria, } \\
\text { especially cyanobacteria }\end{array}$ & all & primary producers & Archean-Recent \\
\hline Acritarchs & chiefly onshore/offshore pelagic & primary producers & $\begin{array}{l}\text { Paleoproterozoic- } \\
\text { Recent }\end{array}$ \\
\hline Dinoflagellates & oceanic, nearshore, lacustrine & primary producers & Silurian?-Recent \\
\hline $\begin{array}{l}\text { Coccolithophorids } \\
\text { and related calcareous algae }\end{array}$ & $\begin{array}{l}\text { oceanic, eutrophic } \\
\text { to oligotrophic }\end{array}$ & primary producers & Triassic-Recent \\
\hline Silicoflagellates & oceanic & $\begin{array}{l}\text { primary producers; } \\
\text { secondary consumers? }\end{array}$ & Cretaceous-Recent \\
\hline Diatoms & $\begin{array}{l}\text { oceanic, chiefly } \\
\text { eutrophic; lacustrine }\end{array}$ & primary producers & Cretaceous-Recent \\
\hline Foraminifera & $\begin{array}{l}\text { benthic. } \\
\text { pelagic }\end{array}$ & $\begin{array}{l}\text { herbivorous, omnivorous, } \\
\text { carnivorous }\end{array}$ & $\begin{array}{l}\text { Cambrian-Recent; Jurassic-Recent } \\
\text { for pelagic forms }\end{array}$ \\
\hline Radiolarians & oceanic & herbivorous, carnivorous & Cambrian-Recent \\
\hline Tintinnids & neritic, oceanic & herbivorous, carnivorous & Ordovician-Recent \\
\hline Metazoa & all & $\begin{array}{l}\text { herbivorous, omnivorous, } \\
\text { carnivorous }\end{array}$ & Ediacaran-Recent \\
\hline Land plants & terrestrial, minor marine & primary producers & Silurian-Recent \\
\hline
\end{tabular}

${ }^{\mathrm{a}}$ Modified from Lipps and Culver [2002] and Lipps [1993].

1997]. Some of these cysts may have been prokaryotes or benthic protists [Butterfield, 1997]. The pelagic ecosystems had changed from one dominated or solely made up of prokaryotes to one with nano- to microphytoplankton that were oxygenic photosynthesizers.

[12] In the Mesoproterozoic, the pelagic biotas were similar to the Paleoproterozoic but diversity was probably greater. Benthic ecosystems also became more complex with diversity and abundance greater in shallow than in deep-water settings [Javaux et al., 2001]. Evolution's tempo increased with the addition of red and green algae.

[13] In the Neoproterozoic, protists diversified [Porter, 2004], while the total biodiversity remained low compared to later times [Knoll, 2003]; small, early multicellular stem metazoans may have been widespread, but evidence is lacking [Lipps, 1992; Lipps and Valentine, 2004]. A bacterial trophic loop was likely present in Early Neoproterozoic seas and by then, phytoplankton and their organic contributions, as well as herbivorous, carnivorous, and consumer protists, were part of it. Benthic mats and stromatolites, including both prokaryotes and protists, were common. A second Snowball Earth period of global glaciations occurred from about 750 to $600 \mathrm{Ma}$ [Kirschvink, 1992], just before the appearance of metazoans and a more complex ecosystem [Narbonne, 2005]. Acritarchs occur through this entire interval varying in diversity but without mass extinctions [Vidal and Moczydlowska-Vidal, 1997]. If the oceans were covered completely with ice, life would have been severely restricted for lack of primary production. It did not go extinct, because the fossil record of protists is continuous through this long interval. Life could have survived in refuges such as cracked and fissured ice, in and near holes in the ice, and near volcanic vents that either provided nearsurface, ice-free, or suitable deep-sea habitats. In either scenario, primary production might have been constrained to lower latitudes, but it could have supported complex trophic interactions in the pelagic and benthic biotas.

[14] The first animal fossils appeared at about $600 \mathrm{Ma}$ [Barford et al., 2002], including sponge and animal embryo fossils. Metazoans or their immediate precursors had evolved earlier from choanoflagellate protists [Medina et al., 2003; King, 2004] although a good date for this divergence is uncertain. These earliest animals, all of which lacked hard skeletons, are preserved either as body impressions or tracks. They diversified into more than 250 known forms [Fedonkin, 1992; Runnegar, 1992a], recorded from all continents except Antarctica. This biota lived for over 60 million years, comprising precursors to the later metazoans [Lipps and Valentine, 2004; Narbonne, 2005], including the first sponges and probably cnidarians [Dewel et al., 2001; Valentine, 2002], although some fossils, which were thought to belong to the Ediacaran biota likely represent other organisms such as algae [Lipps and Valentine, 2004]. The Ediacaran fossils are now considered to be mostly metazoans [Collins et al., 2000; Fedonkin, 1992; Fedonkin and Waggoner, 1997; Jenkins, 1992; Knoll and Carroll, 1999; Martin et al., 2000; Narbonne, 2005; Runnegar, 1992b; Waggoner, 1995].

\subsection{Phanerozoic (0.542 to $0.0 \mathrm{Ga})$}

[15] The Ediacaran fauna was succeeded by a host of diversified metazoans. Within a few million years, the burrowing animals, animals covered with multiple plates and scales, and finally all the major phyla of animals, most of the other fossilizable eukaryotes, and many photosynthesizing organisms appeared [Valentine et al., 1991; Valentine, 2004; Lipps and Culver, 2002]. For microorganisms, six major evolutionary developments occurred during the Phanerozoic: (1) a decline in the abundance and a more restricted distribution of bacterial structures (mats and stromatolites), possibly because of grazing metazoans; (2) evolution of skeletonized benthic foraminifera and siliceous plankton in the Cambrian; (3) the appearance of inferred symbiosis between reef organisms and algal symbionts, including larger foraminifera in mid to late Paleozoic shallow carbonate shelf environments; (4) the first appearance and diversification of major groups of organic-walled, siliceous and calcareous phyto- and zooplankton in the mid-Mesozoic; (5) Mesozoic radiation of deep water, reef, and nearshore biotas; and (6) mass extinctions and rediversification of marine species at the ends of the Paleozoic and Mesozoic, as well as lesser extinctions at several other times. Meta- 


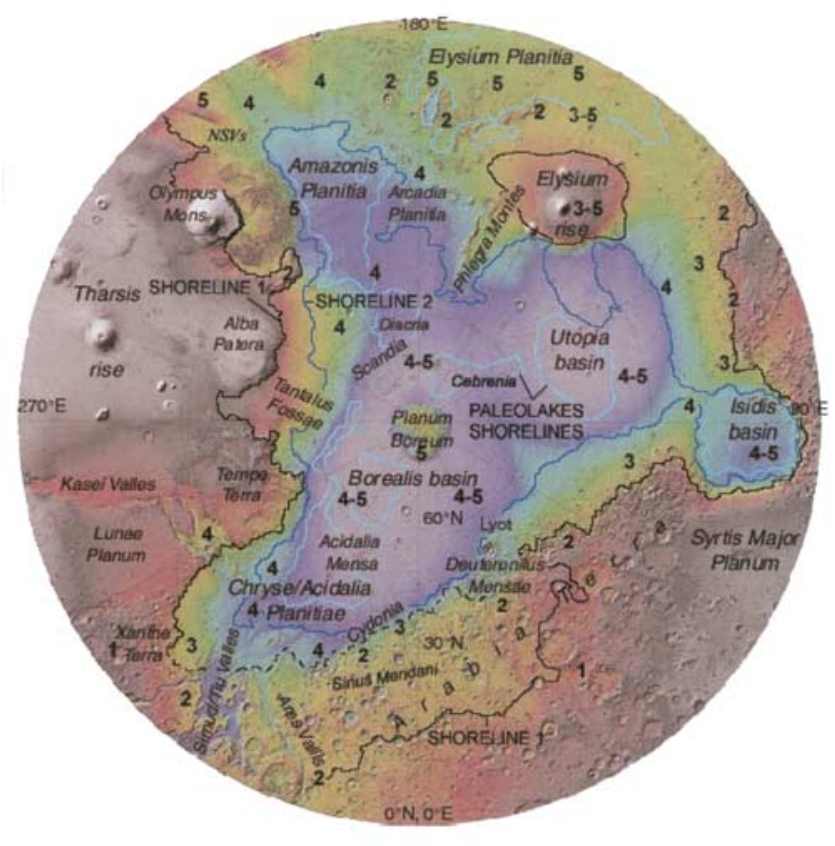

Figure 2. Topographic shaded relief map of the northern hemisphere of Mars constructed from Mars Orbiter Laser Altimeter (MOLA) data showing major geographic features of the northern hemisphere, including possible oceanic shorelines and paleolakes, after Fairén et al. [2003]. State information (numbers) corresponds to stage information in Figure 1. Polar stereographic projection; scale varies with latitude.

zoans underwent similar, if not identical, events in their own evolution.

\section{History of the Martian Environment}

[16] While the issue of how stable liquid water on the Martian surface cannot be satisfactorily resolved at the present time, recent geomorphological, geochemical, and elemental evidence compiled from orbiting spacecraft (e.g., Mars Express and Mars Odyssey, and the MER rovers Opportunity and Spirit), seems to confirm a wet Mars during some time in its early recorded history [Boynton et al., 2002; Squyres et al., 2004; Rieder et al., 2004; Gendrin et al., 2005] (see also investigations by Scott et al. [1995] and Baker [2001] based on Mariner and Viking data). Hypotheses to explain this are numerous (well reviewed by Carr [2000]), and generally involve either a warm and wet climate, or a cold and dry climate punctuated by episodic water activity.

[17] The first set of hypotheses to explain water-related features on the surface of Mars can be summarized as follows: initially, a warm and wet global climate may have occurred at least into the Middle Noachian followed by persisting dry and cold periods interrupted mainly by shortduration pulses (perhaps $10^{3}$ to $10^{4}$ years [Baker et al., 1991]) of endogenic-driven activity, especially at Tharsis and the surrounding regions [Dohm et al., 2001a; Anderson et al., 2001]. Catastrophic flooding and ponding occurred in the northern plains through time to form bodies of water ranging in size from oceans to lakes [Fairén et al., 2003] (Figures 1 and 2), under possibly acidic aqueous conditions [e.g., Fairén et al., 2004]. On the basis of their radiativeconvective climate model, Pollack et al. [1987] concluded that $\mathrm{CO}_{2}$ pressures of 1 to 5 bar would have been required to keep the surface temperature above the freezing point of water, corresponding to globally and orbitally averaged conditions and a $30 \%$ reduction in solar luminosity of the early Sun. They claim that the most likely mechanism by which these pressures could have been achieved was the thermal decomposition of carbonate rocks caused directly and indirectly (through burial) by intense, global-scale volcanism possibly sufficient to induce episodes of climate warming [Phillips et al., 2001; Solomon et al., 2005]. Outgassing models indicate that at least $140 \mathrm{mbar}$, and possibly as much as 3000 mbar of $\mathrm{CO}_{2}$, could have been placed into the Martian atmosphere [Kahn, 1985], though Kasting [1991] argued that the greenhouse effect of gaseous $\mathrm{CO}_{2}$ and $\mathrm{H}_{2} \mathrm{O}$ would not be sufficient to ensure stable liquid water on the Martian surface. Sagan and Chyba [1997] pointed out that reduced greenhouse gases such as $\mathrm{CH}_{4}$ and $\mathrm{NH}_{3}$ may have contributed to an early Mars warm enough to maintain liquid water on its surface. Under the fainter Sun early in Solar System history, certain groups of anaerobic bacteria pumped out large amounts of methane on Earth, thereby keeping the early climate warm and inviting [Kasting and Siefert, 2002], and putative organisms on early Mars could have done the same. Additionally, carbon dioxide ice clouds in the troposphere may have contributed to warming early Mars as ice particles reflected the outgoing thermal infrared radiation back to the surface [Forget and Pierrehumbert, 1997]. Cloud warming mechanisms are complicated, however, because the amount of surface warming depends on many details, including particle size, cloud height, cloud optical depth, and fractional cloud cover [Kasting, 1997]. Destabilization of clathrates by small decreases in pressure or increases in temperature would liberate methane, which could saturate an ocean with the excess migrating up the water column and being released into the atmosphere, contributing to the global greenhouse effect [Fairén et al., 2005]. In fact, methane has been detected in the Martian atmosphere [Formisano et al., 2004] and introduction of methane in the atmosphere by biogenic sources among other possibilities (e.g., volcanisms, water/basalt interactions) has been addressed previously by Max and Clifford [2000].

[18] The second set of hypotheses invokes mechanisms that rely mainly on local thermal energy sources to drive hydrologic activity such as valley formation [e.g., Carr and Head, 2003] within a freezing dry climate [Shuster and Weiss, 2005]. These mechanisms include groundwater sapping, runoff, mass wasting, and/or episodic flooding [Pieri, 1976; Mars Channel Working Group, 1983; Baker and Partridge, 1986; Carr, 1995] due to (1) hydrothermal circulation induced by an early, higher geothermal gradient or local hydrothermal sources such as impact craters, intrusions, or volcanoes [Newsom, 1980; Mouginis-Mark et al., 1984; Brakenridge et al., 1985; Mouginis-Mark, 1985, 1990; Squyres et al., 1987; Gulick and Baker, 1989, 1990; Wilhelms and Baldwin, 1989; Clifford, 1993; Squyres and Kasting, 1994; Scott et al., 1995; Tanaka et al., 1998], (2) intense seismic shaking caused by impacts and mars- 
Table 2. Elevation, Area, Volume, and Depth (for Present-Day Topography) of the Basins Proposed by Fairén et al. $[2003]^{\mathrm{a}}$

\begin{tabular}{lccc}
\hline & Meridiani Shoreline & Arabia Shoreline & Deuteronilus Shoreline \\
\hline Mean elevation, $\mathrm{m}$ & -1500 & -2090 & -3792 \\
Basin area, $10^{7} \mathrm{~km}^{2}$ & 5.35 & 4.67 & 2.47 \\
Volume, $10^{7} \mathrm{~km}^{3}$ & $10.7-15.5$ & $7.7-11.1$ & $1.4-2.0$ \\
Mean depth, $\mathrm{km}$ & $1.99-2.89$ & $1.64-2.38$ & $0.56-0.81$ \\
\hline
\end{tabular}

${ }^{a}$ Note that the Meridiani shoreline is derived from two different proposed shorelines [Parker et al., 1989, 1993; Edgett and Parker, 1997], as shown in Figure 2.

quakes [Clifford, 1993; Tanaka et al., 1998; Dohm et al., 2001b; Segura et al., 2002], or (3) pressurization of watersaturated crustal materials by tectonic deformation [MacKinnon and Tanaka, 1989; Tanaka et al., 1998].

[19] An alternative interpretation of the evidence described above includes a variation of Martian orbital parameters [see Carr, 1990; Touma and Wisdom, 1993; Laskar and Robutel, 1993] and related environmental/ climatic changes. Though numerous exogenic- and endogenic-related processes may have contributed to the trajectory of possible life on Mars, here we focus on three candidate scenarios, which are not necessarily mutually exclusive, including (1) a mostly cold and dry Mars with liquid water on its surface or beneath ice sheets for prolonged periods; (2) a mostly cold and dry Mars, which was periodically subjected to transient melting of groundwater leading to precipitation, flooding, and surface water in a liquid or frozen state for relatively brief periods; and (3) the presence of oceans and a warm humid atmosphere into at least the Middle to Late Nochian (Figure 2, Table 2).

\section{Trajectories for Life on Mars}

[20] If water and an atmosphere containing carbon and nitrogen were present for a sustained period in the early history of Mars, the origin or sustenance of life on that planet seems probable. Once formed or established on Mars, life presumably would have followed a trajectory determined largely by natural selection operating on inherent variation in existing populations of organisms. The trajectory of life on Mars therefore would be expected on theoretical grounds to have undergone changes dictated by the relative stability and change in the environment [Campbell, 1996]. Most organisms remain relatively unchanged during their evolutionary life spans because their environments do not change. While life may arise or take hold fairly quickly, it has little propensity to evolve rapidly if the environments are stable. Those traits that are successful in a particular environment are therefore selected more strongly, resulting in long-enduring species. On the other hand, changes in either the biotic or abiotic environment can alter the pace and direction of evolution relatively rapidly, thereby generating both change in existing forms as well as diversification of new forms. As described in the previous section, the planetary history of Mars shows episodes of both radical change and prolonged gross stability, hence affecting the evolutionary trajectory in different ways at different times of life on Mars.

\subsection{Scenario 1}

[21] If Mars was cold and dry for most of its history with periodic and prolonged presence of surface water beneath ice sheets (referred to as Scenario 1), life could have retreated from an earlier warm epoch to liquid subsurface water habitats, beneath ice sheets, and to liquid groundwater beneath the permafrost. On the other hand, life also may have originated in ice, such as in channels where solutes are squeezed out as crystallization progresses. If life originated on Mars, the first organisms would likely have been simple heterotrophs surviving on the consumption of high-energy organic molecules available in the primordial Martian water bodies. Chemoautotrophic organisms, functioning independently from preexisting organic nutrients, may have evolved from others. Given the availability of sunlight as an energy source on Mars, phototrophic organisms may have evolved as well. On Earth, phototrophs may have evolved in as little as 10 million years [Lazcano and Miller, 1994]. If Martian phototrophs ever produced oxygen as a metabolic by-product, the oxygen has since escaped to space or oxidized surface minerals. Indeed, the oxidized state of the surface today indicates the possibility that oxygen sufficient to support some oxidative metabolism could have been present at an earlier stage of planetary evolution. However, the very low level of oxygen in the Martian atmosphere today renders the survival of macroorganisms using oxidative metabolism highly unlikely.

[22] Under the conditions of Scenario 1, Mars may never have evolved a biosphere as encompassing as that of Earth. Even if prokaryotic-like heterotrophs, and subsequently chemotrophs and phototrophs, had evolved in or at the margins of ancestral Martian bodies of water, as the planet cooled and the water froze beneath ice sheets or retreated underground, psychrophilic microbes capable of surviving for long periods of time beneath the ice cover may have evolved or diversified. Even on Earth under the moderating influence of a denser, humid atmosphere, simple prokaryotic forms have dominated over the entire history of life, although other complex forms eventually radiated from them and their ancestors.

[23] Phototrophs, by analogy with their appearance on Earth and under suitable conditions according to Scenario 1, would have possibly evolved on Mars, and would have allowed the emergence of ecosystems roughly comparable to those on Earth during the late Archean and early Proterozoic. Organisms as complex as single-celled eukaryotes could have evolved. As the atmosphere dissipated and the water habitats disappeared, however, enhanced UV radiation, hypobaric stress, and desiccation at the Martian surface would likely have led to the extinction of all surface dwelling organisms. Chemoautotropic psychrophiles living in liquid groundwater or protected under an ice cover would be the most likely surviving organisms.

[24] Depending on their total biomass, some of the heterotrophic organisms may have survived by using the 
chemotrophic organisms as a food resource, or may have scavenged organic molecules from abiogenic sources (e.g., from hydrothermal sources [Jannasch, 1995; MacDonald et al., 2004], for example, via Fischer-Tropsch synthesis [Foustoukos and Seyfried, 2004]). Among the few sites known on Earth with chemotrophic organisms solely supported by chemical energy are deep basalt aquifers [Stevens and McKinley, 1995], hydrothermal vents, and anoxic sediments. Analogous ecosystems independent of photosynthesis could have existed on Mars, perhaps best exemplified in and near Tharsis, where long-lived, magma-water interactions and basin-infilling lavas and possible sedimentary sequences have been recorded [Dohm et al., 2001a; Komatsu et al., 2004]. Bioenergetic models of other energy sources such as thermosynthesis, kinetic energy, or osmotic gradients have been shown to be theoretically feasible where light as an energy source is not available [SchulzeMakuch and Irwin, 2002, 2004; A. W. J. Muller and D. Schulze-Makuch, Thermal energy and the origin of life, submitted to Origin of Life and Evolution of the Biosphere, 2005].

\subsection{Scenario 2}

[25] In the case of a mostly cold and dry Mars for most of its history, but subject to (1) periodic global flooding triggered by episodic volcanism and meteor bombardment, and (2) localized flow from snow or ice melt or groundwater eruptions (referred to here as Scenario 2), life could have retreated to the subsurface, in groundwater or in protected places such as subterranean voids, including lava tubes, fractures, fissures, and caverns, which may still be extensive on the planet [e.g., Rodriguez et al., 2005a, 2005b]. Such life may have developed cycles alternating between dormant and proliferative forms. Given radical, fluctuating changes in the environment with periodically favorable conditions on the Martian surface, strong selection may have occurred for enhancing chemoautotrophy and alternative energy sources, which could have generated a diverse range of chemical pathways (some of which may not exist on Earth), but also other energy sources such as thermosynthesis discussed above. Fewer potential habitats would exist, but they would not be as fragmented as under Scenario 1, and periodically organisms would thrive in a surface ocean or at least under surface conditions with abundant liquid water, enhancing evolutionary possibilities. Thus the question is whether hundreds of millions of years of dry Mars can maintain a biosphere sufficient to respond to growth and selection during much shorter warm periods. If the answer is yes, the consequences would be profound and many evolutionary innovations could be expected.

[26] Some of the subsurface organisms under Scenario 2 may have evolved as efficient scavengers. They would have utilized chemical sources of energy, possibly thermal sources, and would reasonably be located near sites of volcanic activity in large numbers. Organisms in the subsurface or below ice may survive for long periods, even in dormant states for some periods of time, if they are protected from ambient radiation from the rocks. Examples include (1) cryptoendolithic cyanobacteria in Antarctica, which are observed to exist in soil of only a few mm thickness [e.g., Friedmann, 1982; Nienow et al., 1988; Friedmann et al., 1993]; (2) terrestrial iron-metabolizing bacteria that develop self-protection mechanisms, in which ferric iron produced by iron metabolism provides high protection against radiation [Gómez et al., 2003]; and (3) Bacillus endospores, which have been reported to survive under space conditions [e.g., Nicholson et al., 2000]. Though apparently lifeless during the long dry and cold periods, Mars could potentially bloom with life reproducing at a high rate during the occurrences of liquid water on its surface. Thus, under Scenario 2, two life styles could exist on Mars today. The first possibility consists of simple organisms in subterranean environments (including cavities and groundwater reservoirs), ideally adapted to scavenge nutrients and comparable to the chemotrophic psychrophiles postulated in Scenario 1. The other possibility consists of living microorganisms with dormant forms persisting near the surface and becoming active only during suitable surface conditions. Some of the latter organisms might be active to a limited extent in restricted environments such as groundwater or in lava tubes. Both types of organisms under Scenario 2 would be expected to differ considerably from their ancestral forms because of the recurrent cycles of directional selection driven by the alternation of brief warmer wetter periods with sustained periods of global cooling and surface desiccation.

\subsection{Scenario 3}

[27] In the third scenario, we consider an Earth-like water world (e.g., such as during the Archean when elevated magmatism is recorded) with extensive magmatic-driven activity, including elevated hydrothermal activity for a prolonged period, at least until Tharsis became well established before the end of the Noachian Period [Dohm et al., 2001a] (Figure 1). This would be followed by a gradual loss of atmosphere and desiccation of the surface (for example, geologic mapping and GIS-based comparative analysis of the paleotectonic information compiled for the Thaumasia region of Mars shows that magmatic-driven activity was an order of magnitude greater during the Noachian than in the Late Hesperian [Dohm et al., 2001b]). In this scenario, life could have evolved as on Earth with the origin of heterotrophic, chemotrophic, and phototrophic organisms. Although the history of life on Earth might reflect inherent constraints on the rate of evolution, this period might have provided sufficient time for the evolution of eukaryote-like and multicellular organisms on Mars. An additional difficulty for most eukaryote-like organisms may have been the absence of an oxygen-rich atmosphere. Nevertheless, given the only example of evolutionary history with which we are familiar, the possibility for the evolution of eukaryote-like and multicellular organisms on Mars cannot be dismissed. In any event, even under this scenario, phototrophic and heterotrophic organisms probably would have become extinct as the planet dried, but fossils of any of them might be found on or near the surface. Surviving forms would likely be unicellular or simple multicellular, mostly chemoautotrophic, and occupants of subterranean environments.

\section{Fossils on Mars?}

[28] While microbes can live in the subsurface on Earth, most organisms of all types live in abundance only at the surface or below surface waters. The latter is clearly not true on Mars now, nor perhaps has it been for a long time. The 
subsurface biota on Earth has no known fossil record, although living bacteria have been reported from Permian salt deposits [Satterfield et al., 2005]. Thus, although microbial life may have been present on Mars for a long time, its fossil record may be extremely patchy in time and space, or absent.

[29] Microbial fossils on Earth are contained chiefly in aquatic deposits. Microorganisms have always dominated these environments; indeed for most of the geologic record, ecosystems consisted wholly of them, and later when larger animals and plants appeared, they still provided most of the primary production and consumption. Millions of unknown or poorly known species of unskeletonized bacteria and archaea [Torsvik et al., 2002] and protists [Patterson, 1999] produce no fossils at all [Lipps and Culver, 2002]. Yet microfossils and microbial traces are quite abundant in the fossil record of Earth, although they represent only a few major lineages. Microorganisms also eventually occupied every habitat in Earth's aquatic environments from the deepest oceans to marginal lagoons and marshes to fresh waters, damp places, and even snow and ice as long as liquid water was available. Living protists with fossil records have a multitude of complex trophic styles [Azam, 1998]; hence their roles in ancient ecosystems were likely similarly varied. The early evolution of life on Mars and Earth may be inferred or reconstructed by reference to energy acquisition and trophic structures. For Earth, trophic inferences of ancient forms are possible on the basis of the properties of living groups of related organisms and cooccurring assemblages.

[30] Fossils of bacteria are rarely preserved as cells, but fossil microbial mats and the stromatolites they built are relatively common back to the Archean. Among protists are included benthic and planktic primary producers, microherbivores, and micro-carnivores which are also commonly to abundantly preserved, especially in Phanerozoic rocks. Prior to the Phanerozoic, single-celled eukaryotes are known primarily from acritarchs, which appeared around $1.8 \mathrm{Ga}$. These fossils represent photosynthetic forms, but their affinities are not known with certainty; a few are bacteria, some were benthic, while many others were pelagic. In later geologic time, other protists came to dominate the fossil record, but they still represent a very small proportion of the protists that probably existed. Judging from today's seas, bacteria, naked protists, and unfossilizable larger zooplankton were likely present and important, but largely unrecorded in the fossil record. If life is present on Mars, it most likely has remained microbial under either of the two most reasonable scenarios; thus their actual fossils would be difficult to find. However, microbial mats, microbialites, and stromatolites could occur in ancient aquatic sites or on damp soils. Putative Martian organisms could be fossilized under very limited environmental conditions in the same way as those preserved in the Early Archean formations by hydrothermal silica or other hydrothermal fluids (calcium carbonate or iron oxides), or even evaporites [Westall, 2005].

\section{Discussion}

[31] In its early stages, Mars provided a variety of environments as on Earth [Westall, 2005], probably includ- ing shallow water, benthic and pelagic realms, littoral, and deeper-water environments below the wave base in standing water [Cabrol and Grin, 2005]. Mineralogic energy sources may have been sufficient to support as much chemolithotrophic life on Mars in its first 10-50 million years as on early Earth [Jakosky and Shock, 1998]. Volcanic and hydrothermal activity would have been strong on early Mars, although less by a factor of 100 than on Earth [Jakosky and Shock, 1998]. However, some sites probably existed on Mars that have been active for a large part of its history (e.g., the Tharsis complex). An origin of life at sites of hydrothermal activity is thus also possible under Martian conditions. However, the smaller size of Mars would imply that the planet cooled down more quickly and water condensed on the surface earlier than on Earth. This may not have inhibited life, because liquid water beneath an ice cap and heated from below by hydrothermal activity may in fact provide a very suitable environment. Also, if the first cells originated under hydrothermal conditions, these organisms would have shortly (million years range) encountered their first evolutionary challenge. Thermophilic life would have had to adapt to the gradually colder and dryer conditions, culminating in a psychrophilic life style. However, once psychrophilic forms had evolved, life on Mars could have remained in principle relatively unchanged until today if the environments did not change. However, Mars may have undergone major changes, such as the recent ice age from 2.1 to $0.4 \mathrm{Ma}$ that affected the planet to midlatitudes [Head et al., 2003], so life also could have continued to evolve in specialized ways.

[32] Mars may have had plate tectonic activity [Sleep, 1994; Connerney et al., 1999] that ceased early in its history [Baker et al., 2002; Fairén and Dohm, 2004]. The later lack of plate tectonics would not necessarily have inhibited life, however. From a microbial viewpoint, life occurs on temporal and spatial scales that are many orders of magnitude smaller than geological processes [Westall, 2005]; thus microbial life could have become well-established on Mars before climatic degradation made the surface inhospitable. The transition from plate tectonics to a stagnant-lid regime must have resulted in a multitude of effects, such as a great reduction in the recycling of elements and water, dramatic changes in atmospheric composition and pressure, inability to recover all the carbon sequestered in the sediments, changes in global temperature, and many other factors. This could have resulted in a dramatic change in the biosphere as a whole, with a great mass extinction and the survival of only those species able to adapt to the new conditions. These survivors would include psychrophiles persisting in underground reservoirs, or organisms which are likely to have retreated to fragmented habitats such as sites of volcanic activity and regions of persistent elevated heat flow, perhaps in or near parts of the Tharsis and Elysium volcanic provinces and the region that straddles the two provinces [Dohm et al., 2004; Dohm, 2005].

[33] Without an ozone shield, the Martian land surface may have always been sterile. Life may have been able to exist a short distance below the surface, in cracks, fissures, holes, caverns, and below overhangs where UV radiation could not reach. Life on Earth apparently did not populate the surface before oxygen became abundant and the ozone shield sufficiently protective, but it thrived in shallow water 
and may have also existed in cryptic near-surface habitats. Several centimeters of water provide efficient UV protection. Other protective mechanisms such as organic pigments and other organic compounds derived from dead cells could have been present [Marchant et al., 1991; Schulze-Makuch et al., 2004]. However, the abundance of iron on the Martian surface, now confirmed by the MER rovers [Bell et al., 2004], may have provided a much higher degree of protection against radiation. Since ferric iron is the product of iron metabolism, bacteria capable of metabolizing iron could have provided self-protection [Gómez et al., 2003]. Therefore Mars may not have been devoid of life at the surface, as long as water and biotic or abiotic nutrients were available.

[34] Life on Mars presumably would have spread from its point of origin to populate most of the planet, becoming abundant in liquid surface water pools and early oceans. Its challenge would then have been to survive the radical habitat changes that ensued. Life, once evolved on Earth, proved to be extraordinarily adaptive through natural selection. Despite numerous global catastrophes and recurrent environmental changes, several of which extinguished a large proportion of the species in existence, life has persisted to occupy every suitable habitat on the planet. Life on Mars could likewise be expected to have been fairly tenacious, adapting to the global changes that occurred as the planet passed through cycles of cooling and desiccation.

[35] Dormant microbial states, such as spores or cryptogenic organisms like those found in cold environments on Earth, may have allowed Martian organisms to exist through harsh conditions until the environment became suitable for active life once again (such as during periods of liquid water on the Martian surface). If life evolved far enough on Mars to develop dormant states similar to sporulating bacteria on Earth, it would have been hardy enough to survive new environments that followed in later Martian history.

[36] If Mars has indeed been cold and dry for most of its history, the probability is high that surviving forms of life, if any, would be microbial. Subsurface habitats on Earth are populated almost exclusively by microbial organisms at depths more than a few meters underground, due probably to the low level of nutrients, the relative lack of chemical cycling, and the impediments to growth and movement that macroorganisms encounter underground. Those few macroorganisms that have adopted fossorial life styles derive from ancestors that evolved on the surface and still depend on surface ecosystems for nutrients. Even those species adapted to cave life likewise evolved from non-cave dwelling ancestors. Thus, for the Martian subsurface to be populated by anything other than microorganisms would imply a prolonged opportunity for evolution in the oceans or at the surface, probably extending to recent times. Until this possibility (Scenario 3) is ruled out, macroorganisms or their fossils conceivably could be found on Mars. Under what appears to be the more likely Scenarios 1 and 2, life on Mars, if it persists, is most likely to be microbial.

[37] The scenarios we have proposed for the evolution of life on Mars suggest two search strategies for future missions. One strategy should concentrate on materials deposited in water-laid sediments or cold or hot spring deposits. If fossils are preserved in such sediments, they would likely be microscopic and require examination at high magnification by instruments at Mars or of samples returned to Earth. Relevant rock types would include fine-grained detrital sediments or chemical precipitates in former water channels or reservoirs (ponds, lakes or seas), and in chemical precipitates from hydrothermal and cold water deposits. Fossils could be revealed by examination of disaggregated or macerated rocks, or in thin-sections made from those same rocks. The second strategy would be to search for living organisms by subsurface drilling or remote searching of cracks, fissures, overhangs, and caves near the surface. With appropriate instrumentation, samples gathered on site could be scanned for extant, fossil, or dormant microbial organisms by microscopy, and screened for the presence of organic macromolecules by atomic mass spectrometry. Bioindicators for life that even dormant organisms would be expected to exhibit include (1) the presence of complex organic compounds with molecular weights of 1,000 or greater, (2) isotopic fractionation toward the lighter biogenic elements, (3) cellular compartmentalization and boundaries, (4) presence of a chemical that functions as the genetic code, and (5) homochirality. For a more complete list of search parameters for possible alien life the reader is referred to Table 1 of Schulze-Makuch and Grinspoon [2005].

\section{Conclusions}

[38] The most reasonable environmental histories for Mars indicate long dry and cold periods interspersed with warmer and wetter environments. Life could have evolved under early environmental conditions on Mars, have diversified and gone partially extinct under changing conditions, but still be present in liquid water beneath or in ice, in subterranean aqueous reservoirs, especially in regions of elevated heat flow, or in protected habitats such as cracks, fissures, lava tubes or caves. Organisms would likely be chemoautotrophic psychrophiles adapted to a nutrient-poor environment. Or, life may have evolved alternating cycles between dormant and proliferative life-forms, in which case microbes could be present in dormant or semi-dormant forms close to the surface and in proliferative forms in protected habitats. The episodic availability of liquid water on the Martian surface likely promoted evolutionary change. To the extent that water persisted on the surface for a prolonged period, the opportunity for evolution of macroorganisms existed. However, given the harsh environment and the prolonged conditions on the Martian surface hostile to life, it has likely remained in the microbial stage.

\section{References}

Anbar, A., and A. H. Knoll (2002), Proterozoic ocean chemistry and evolution: A bioinorganic bridge?, Science, 297, 1137-1142.

Anders, E. (1989), Prebiotic organic matter from comets and asteroids, Nature, 342, 255-257.

Anderson, R. C., J. M. Dohm, M. P. Golombek, A. F. C. Haldemann, B. J. Franklin, K. L. Tanaka, J. Lias, and B. Peer (2001), Primary centers and secondary concentrations of tectonic activity through time in western hemisphere of Mars, J. Geophys. Res., 106, 20,563-20,585.

Azam, F. (1998), Microbial control of oceanic carbon flux: The plot thickens, Science, 280(5364), 694-696

Bada, J. L., and A. Lazcano (2002), Some like it hot, but not the first biomolecules, Science, 296, 1982-1983.

Baker, V. R. (2001), Water and the Martian landscape, Nature, 412, $228-$ 236 . 
Baker, V. R., and J. B. Partridge (1986), Small Martian valleys: Pristine and degraded morphology, J. Geophys. Res., 91, 3561-3572.

Baker, V. R., R. G. Strom, V. C. Gulick, J. S. Kargel, G. Komatsu, and V. S. Kale (1991), Ancient oceans, ice sheets and the hydrological cycle on Mars, Nature, 352, 589-594.

Baker, V. R., S. Maruyama, and J. M. Dohm (2002), A theory of early plate tectonics and subsequent long-term superplume activity on Mars, Electron. Geosci., 7. (Available at http://lin.springer.de/service/journals/ $10069 /$ free/conferen/superplu/.)

Barford, G. H., F. Albarede, A. H. Knoll, S. Xiao, P. Telouk, R. Frei, and J. Baker (2002), New Lu-Hf and $\mathrm{Pb}-\mathrm{Pb}$ age constraints on the earliest animal fossils, Earth Planet. Sci. Lett., 201, 203-212.

Bekker, A., H. D. Holland, P.-L. Wang, D. Rumble, H. J. Stein, J. L. Hannah, L. L. Coetzee, and N. J. Beukes (2004), Dating the rise of atmospheric oxygen, Nature, 427, 117-120

Bell, J. F., et al. (2004), Pancam multispectral imaging results from the Opportunity Rover at Meridiani Planum, Science, 306, 1703-1709.

Boynton, W. V., et al. (2002), Distribution of hydrogen in the near-surface of Mars: Evidence for subsurface ice deposits, Science, 297, 81-85.

Brakenridge, G. R., H. E. Newsom, and V. R. Baker (1985), Ancient hot springs on Mars: Origins and paleoenvironmental significance of small Martian valleys, Geology, 13(12), 859-862.

Brasier, M. D., O. R. Green, A. P. Jepherat, A. K. Kleppe, M. J. Kranendonk, J. F. Lindsay, A. Steele, and N. V. Grassineau (2002), Questioning the evidence for Earth's oldest fossils, Nature, 416, 76-81.

Brochier, C., and H. Philippe (2002), A non-hyperthermophilic ancestor for bacteria, Nature, 417, 244.

Brocks, J. J., G. A. Logan, R. Buick, and R. E. Summons (1999), Archean microfossils and the early rise of eukaryotes, Science, 285, 1033-1036.

Butterfield, N. J. (1997), Plankton ecology and the Proterozoic-Phanerozoic transition, Paleobiology, 23(2), 247-262.

Cabrol, N. A., and E. A. Grin (2005), Ancient and recent lakes on Mars, in Water on Mars and Life, edited by T. Tokano, pp. 235-260, Springer, New York.

Campbell, N. A. (1996), Biology, Benjamin-Cummings, San Francisco, Calif.

Carr, M. H. (1990), D/H on Mars: The effect of floods, volcanism, impacts and polar processes, Icarus, 87, 210-227.

Carr, M. H. (1995), The Martian drainage system and the origin of valley networks and fretted channels, J. Geophys. Res., 100, 7478-7507.

Carr, M. H. (2000), Martian oceans, valleys, and climate: New insights from Mars Global Surveyor, Astron. Geophys., 41(3), 3.20-3.26.

Carr, M. H., and J. W. Head III (2003), Oceans on Mars: An assessment of the observational evidence and possible fate, J. Geophys. Res., 108(E5), 5042, doi:10.1029/2002JE001963.

Chyba, C. F., P. J. Thomas, L. Brookshaw, and C. Sagan (1990), Cometary delivery of organic molecules to the early Earth, Science, 249, 366-373.

Clifford, S. M. (1993), A model for the hydrologic and climate behavior of water on Mars, J. Geophys. Res., 98, 10,973-11,016.

Collins, A. G., J. H. Lipps, and J. W. Valentine (2000), Modern mucociliary creeping trails and the bodyplans of Neoproterozoic trace-makers, Paleobiology, 26(1), 47-55.

Connerney, J. E. P., M. H. Acuna, P. J. Wasilewski, N. F. Ness, H. Reme, C. Mazelle, D. Vignes, R. P. Lin, D. L. Mitchell, and P. A. Cloutier (1999), Magnetic lineations in the ancient crust of Mars, Science, 284, 794-798.

Davies, P. C. W. (1996), The transfer of viable microorganisms between planets, in Evolution of hydrothermal ecosystems on Earth (and Mars?), pp. 304-314, John Wiley, Hoboken, N. J.

de Duve, C. (1995), Cosmic Dust: Life as a Cosmic Imperative, 350 pp. Basic Books, New York.

Des Marais, D. J. (2000), When did photosynthesis emerge on Earth?, Science, 289, 1703-1705.

Dewel, R. A., W. C. Dewel, and F. K. McKinney (2001), Diversification of the Metazoa: Ediacarans, colonies, and the origin of Eumetazoan complexity by nested modularity, Historical Biol., 15, 93-118.

Dohm, J. M. (2005), The Tharsis and Elysium corridor: A marker for an internally active Mars?, paper presented at Goldschmidt 2005 Conference, Univ. of Idaho, Moscow, 20-25 May.

Dohm, J. M., J. C. Ferris, V. R. Baker, R. C. Anderson, T. M. Hare, R. G. Strom, N. G. Barlow, K. L. Tanaka, J. E. Klemaszewski, and D. H. Scott (2001a), Ancient drainage basin of the Tharsis region, Mars: Potential source for outflow channel systems and putative oceans or paleolakes, J. Geophys. Res., 106, 32,943-32,958.

Dohm, J. M., K. L. Tanaka, and T. M. Hare (2001b), Geologic map of the Thaumasia region of Mars, U.S. Geol. Surv. Geol. Invest. Ser., Map I2650 .

Dohm, J. M., et al. (2001c), Latent outflow activity for western Tharsis, Mars: Significant flood record exposed, J. Geophys. Res., 106, 12,30112,314 .
Dohm, J. M., J. C. Ferris, N. G. Barlow, V. R. Baker, W. C. Mahaney, R. C. Anderson, and T. M. Hare (2004), The Northwestern Slope Valleys (NSVs) region, Mars: A prime candidate site for the future exploration of Mars, Planet. Space Sci., 52, 189-198.

Edgett, K. S., and T. J. Parker (1997), Water on early Mars: Possible subaqueous sedimentary deposits covering ancient cratered terrain in western Arabia and Sinus Meridani, Geophys. Res. Lett., 24, 2897-2900.

Fairén, A. G., and J. M. Dohm (2004), Age and origin of the lowlands of Mars, Icarus, 168, 277-284.

Fairén, A. G., J. M. Dohm, V. R. Baker, M. A. de Pablo, J. J. Ruiz, J. C. Ferris, and R. C. Anderson (2003), Episodic flood inundations of the northern plains of Mars, Icarus, 165, 53-67.

Fairén, A. G., D. Fernández-Remolar, J. M. Dohm, V. R. Baker, and R. Amils (2004), Inhibition of carbonate synthesis in acidic oceans on early Mars, Nature, 431, 423-426.

Fairén, A. G., J. M. Dohm, E. R. Uceda, A. P. Rodríguez, V. R. Baker, D. Fernández-Remolar, D. Schulze-Makuch, and R. Amils (2005), Prime candidate sites for astrobiological exploration through the hydrogeological history of Mars, Planet. Space Sci. 53, 1355-1375.

Farquhar, J., H. Bao, and M. Thiemens (2000), Atmospheric influence of Earth's earliest sulfur cycle, Science, 289, 756-758.

Fedonkin, M. A. (1992), Vendian faunas and the early evolution of Metazoa, in Origin and Early Evolution of the Metazoa, edited by J. H. Lipps and P. W. Signor, pp. 87-129, Springer, New York.

Fedonkin, M. A., and B. M. Waggoner (1997), The Late Precambrian fossil Kimberella is a mollusc-like bilaterian organism, Nature, 388, $868-871$.

Forget, F., and R. T. Pierrehumbert (1997), Warming early Mars with carbon dioxide clouds that scatter infrared radiation, Science, 278, 12731276.

Formisano, V., S. Atreya, T. Encrenaz, N. Ignatiev, and M. Giuranna (2004), Detection of methane in the atmosphere of Mars, Science, 306, $1758-1761$.

Foustoukos, D. I., and W. E. Seyfried (2004), Hydrocarbons in hydrothermal vent fluids: The role of chromium-bearing catalysts, Science, 304, $1002-1005$.

Friedmann, E. I. (1982), Endolithic microorganisms in the Antarctic cold desert, Science, 215, 1045-1053.

Friedmann, E. I., L. Kappen, M. A. Meyer, and J. A. Nienow (1993), Longterm productivity in the cryptoendolithic microbial community of the Ross Desert, Antarctica, Microbial Ecol., 25, 51-69.

Gendrin, A., et al. (2005), Sulfates in Martian layered terrains: The OMEGA/Mars Express view, Science, 307(5715), 1587-1591, doi:10.1126/science. 1109087

Gomes, R., H. F. Levison, K. Tsiganis, and A. Morbidelli (2005), Origin of the cataclysmic late heavy bombardment period of the terrestrial planets, Nature, 435, 466-469.

Gómez, F. A. Grau, L. Vázquez, and R. Amils (2003), UV radiation effects over microorganisms and study of protective agents, paper presented at III European Workshop on Exo/Astrobiology, Eur. Space Agency, Madrid.

Gómez, F., D. Fernández-Remolar, E. González-Toril, and R. Amils (2004), The Tinto River, an extreme Gaian environment, in Scientists Debate Gaia, edited by S. H. Schneider et al., pp. 321-333, MIT Press, Cambridge, Mass.

Goodwin, B. (1994), How the Leopard Changed Its Spots: The Evolution of Complexity, Charles Scribner's Sons, New York.

Gradstein, F. M., J. G. Ogg, A. G. Smith, W. Bleeker, and L. J. Lourens (2004), A new geologic time scale with special reference to Precambrian and Neogene, Episodes, 27(2), 83-100.

Greeley, R., and J. E. Guest (1987), Geologic map of the eastern equatorial region of Mars, U.S. Geol. Surv. Misc. Invest. Ser. Map I-1802B, scale $1: 15,000,000$.

$\mathrm{Gu}$, X. (1997), The age of the common ancestor of eukaryotes and prokaryotes: Statistical inferences, Mol. Biol. Evol., 14(8), 861-866.

Gulick, V. C., and V. R. Baker (1989), Fluvial valleys and Martian palaeoclimates, Nature, 341, 514-516.

Gulick, V. C., and V. R. Baker (1990), Origin and evolution of valleys on Martian volcanoes, J. Geophys. Res., 95, 14,325-14,334.

Hartmann, W. K. (2001), Martian upland history: Inconsistencies and constraints, Proc. Lunar Planet. Sci. Conf. 32nd, abstract 1794.

Head, J. W., J. F. Mustard, M. A. Kreslavsky, R. E. Milliken, and D. R. Marchant (2003), Recent ice ages on Mars, Nature, 426, 797-802.

Hedges, S. B., H. Chen, S. Kumar, D. Y. C. Wang, A. Thompson, and H. Watanabe (2001), A genomic timescale for the origin of eukaryotes, BMC Evol. Biol., 1, 4-13.

Holland, H. D. (1973), The oceans: A possible source of iron in ironformations, Econ. Geol., 68, 1169-1172.

Holland, H. D. (1984), The Chemical Evolution of the Atmosphere and Oceans, Princeton Univ. Press, Princeton, N. J. 
Horneck, G., H. Buecker, and G. Reitz (1994), Long-term survival of bacterial spores in space, Adv. Space Res., 14, 41-45.

Jakosky, B. M., and E. L. Shock (1998), The biological potential of Mars, the early Earth, and Europa, J. Geophys. Res., 103(E8), 19,35919,364

Jannasch, H. W. (1995), Microbial interaction with hydrothermal fluids, in Seafloor Hydrothermal Systems: Physical, Chemical, Biological, and Geological Interactions, Geophys. Monogr. Ser., vol. 91, edited by S. E. Humprhis et al., pp. 273-296, AGU, Washington, D. C.

Javaux, E. J., A. H. Knoll, and M. R. Walter (2001), Morphological and ecological complexity in early eukaryotic ecosystems, Nature, 412(6842), $66-69$.

Jenkins, R. J. F. (1992), Functional and ecological aspects of Ediacaran assemblages, in Origin and Early Evolution of the Metazoa, edited by P. W. Signor, pp. 131-176, Springer, New York

Kahn, R. (1985), The evolution of $\mathrm{CO}_{2}$ on Mars, Icarus, 62, 175-190.

Kasting, J. F. (1991), $\mathrm{CO}_{2}$ condensation and the climate of early Mars, Icarus, 94, 1-13.

Kasting, J. F. (1997), Update: The early Mars climate question heats up, Science, 278, 1245 .

Kasting, J. F., and J. L. Siefert (2002), Life and the evolution of Earth's atmosphere, Science, 296, 1066-1068.

Katz, L. A. (1999), The tangled web: Gene genealogies and the origin of eukaryotes, Am. Nat., 154, suppl., S137-S145.

Kauffman, S. A. (1995), At Home in the Universe: The Search for Laws of Self-Organization and Complexity, Oxford Univ. Press, New York.

King, N. (2004), The unicellular ancestry of animal development, Dev. Cell, 7, 313-325.

Kirschvink, J. L. (1992), Late Proterozoic low-latitude globlal glaciation: The Snowball Earth, in The Proterozoic Biosphere: A Multidisciplinary Study, edited by J. W. Schopf and C. Klein, pp. 51-52, Cambridge Univ. Press, New York.

Kirschvink, J. L., E. J. Gaidos, L. E. Bertani, J. N. Beukes, J. Gutzmer, L. N. Maepa, and R. E. Steinberger (2000), Paleoproterozoic snowball Earth: Extreme climatic and geochemical global change and its biological consequences, Proc. Natl. Acad. Sci. U. S. A., 97(4), 1400-1405.

Knoll, A. H. (2003), Life on a Young Planet, 277 pp., Princeton Univ. Press, Princeton, N. J.

Knoll, A. H., and S. B. Carroll (1999), Early animal evolution emerging views from comparative biology and geology, Science, 284, 2129-2137.

Komatsu, G., J. M. Dohm, and T. M. Hare (2004), Hydrogeologic processes of large-scale tectono-magmatic complexes in Mongolia-southern Siberia and on Mars, Geology, 32, 325-328.

Kramers, J. (2001), The smile of the Cheshire Cat, Science, 293, 619-620.

Lahav, N. (1999), Biogenesis: Theories of Life's Origin, 304 pp., Oxford Univ. Press, New York.

Laskar, J., and P. Robutel (1993), The chaotic obliquity of the planets, Nature, 361, 608-612.

Lazcano, A., and S. L. Miller (1994), How long did it take for life to begin and evolve to cyanobacteria?, J. Mol. Evol., 39, 549-554.

Lipps, J. H. (1992), Proterozoic and Cambrian skeletonized protists, in The Proterozoic Biosphere: A Multidisciplinary Study, edited by J. W. Schopf and C. Klein, pp. 237-240, Cambridge Univ. Press, New York.

Lipps, J. H. (1993), Introduction to fossil prokaryotes and protists, in Fossil Prokaryotes and Protests, edited by J. H. Lipps, pp. 1-10, Blackwell Sci., Malden, Mass.

Lipps, J. H., and S. J. Culver (2002), The trophic role of marine microorganisms through time, Paleontol. Soc. Pap., 8, 69-92.

Lipps, J. H., and J. W. Valentine (2004), Late Neoproterozoic Metazoa: Weird, wonderful and ghostly, in Neoproterozoic-Cambrian Biological Revolutions, Paleontol. Soc. Pap. 10, edited by J. H. Lipps and B. Waggoner, pp. 51-66, Paleontol. Soc., New Haven, Conn.

Lowe, D. R. (1992), Major events in the geological development of the Precambrian Earth, in The Proterozoic Biosphere: A Multidisciplinary Study, edited by J. W. Schopf and C. Klein, pp. 67-75, Cambridge Univ. Press, New York.

MacDonald, I. R., et al. (2004), Asphalt volcanism and chemosynthetic life in the Campeche Knolls, Gulf of Mexico, Science, 304, 999-1002.

MacKinnon, D. J., and K. L. Tanaka (1989), The impacted Martian crust: Structure, hydrology, and some geologic implications, J. Geophys. Res., 94(B12), 17,359-17,370.

Marchant, H. J., A. T. Da Vidson, and G. J. Kelly (1991), UV-B protecting compounds in the marine alga Phaeocystis pouchetti from Antarctica, Mar. Biol., 109, 391-395.

Mars Channel Working Group (1983), Channels and valleys on Mars, Geol. Soc. Am. Bull., 94, 1035-1054.

Martin, M. W., D. V. Grazhdankin, S. A. Bowring, D. A. D. Evans, M. A Fedonkin, and J. L. Kirschvink (2000), Age of Neoproterozoic bilatarian body and trace fossils, White Sea, Russia: Implications for metazoan evolution, Science, 288, 841-845.
Max, M. D., and S. M. Clifford (2000), The state, potential distribution, and biological implications of methane in the Martian crust, J. Geophys. Res., 105, 4165-4171

Medina, M., A. G. Collins, J. Taylor, J. W. Valentine, J. H. Lipps, L. Amaral-Zettler, and M. L. Sogin (2003), Phylogeny of Opisthokonta and the evolution of multicellularity and complexity in fungi and metazoan, Int. J. Astrobiol., 2(3), 203-211.

Morowitz, H. J. (1968), Energy Flow in Biology, Elsevier, New York.

Mouginis-Mark, P. J. (1985), Volcano/ground ice interactions in Elysium Planitia, Mars, Icarus, 64, 265-284.

Mouginis-Mark, P. J. (1990), Recent water release in the Tharsis region of Mars, Icarus, 84, 362-373.

Mouginis-Mark, P. J., L. Wilson, J. W. Head, S. H. Brown, L. J. Hall, and K. D. Sullivan (1984), Elysium Planitia, Mars: Regional geology, volcanology, and evidence for volcano-ground ice interactions, Earth Moon Planets, 30, 149-173.

Narbonne, G. M. (2005), The Ediacara biota: Neoproterozoic origin of animals and their ecosystems, Annu. Rev. Earth Planet. Sci., 33, $421-$ 442 .

Newsom, H. E. (1980), Hydrothermal alteration of impact melt sheets with implications for Mars, Icarus, 44, 207-216.

Nicholson, W. L., N. Munakata, G. Horneck, H. J. Melosh, and P. Setlow (2000), Resistance of Bacillus endospores to extreme terrestrial and extraterrestrial environments, Microbiol. Mol. Biol. Rev., 64, 548-572.

Nienow, J. A., C. P. McKay, and E. I. Friedmann (1988), The cryptoendolithic microbial environment in the Ross desert of Antarctica: Light in the photosynthetically active region, Microbial Ecol., 16, $271-289$.

Nisbet, E. G., and N. H. Sleep (2001), The habitat and nature of early life, Nature, 409, 1083-1091.

Parker, T. J., R. S. Saunders, and D. M. Schneeberger (1989), Transitional morphology in the west Deuteronilus Mensae region of Mars: Implications for modification of the lowland/upland boundary, Icarus, 82, 111 145

Parker, T. J., D. S. Gorsline, R. S. Saunders, D. C. Pieri, and D. M. Schneeberger (1993), Coastal geomorphology of the Martian northern plains, J. Geophys. Res., 98, 11,061-11,078.

Patterson, D. J. (1999), The diversity of eukaryotes, Am. Nat., 154, suppl., S96-S124.

Phillips, R. J., et al. (2001), Ancient geodynamics and global-scale hydrology on Mars, Science, 291, 2587-2591.

Pieri, D. C. (1976), Distribution of small channels on the Martian surface, Icarus, 27(1), 25-50.

Pollack, J. B., J. F. Kasting, M. Ricardson, and K. Poliakoff (1987), The case for a wet, warm climate on early Mars, Icarus, 71, 203-224.

Porter, S. M. (2004), The fossil record of early eukaryotic diversification, in Neoproterozoic-Cambrian Biological Revolutions, Paleontol. Soc. Pap. 10, edited by J. H. Lipps and B. Waggoner, pp. 35-50, Paleontol. Soc., New Haven, Conn.

Reysenbach, A.-L., and E. Shock (2002), Merging genomes with geochemistry in hydrothermal ecosystems, Science, 296, 1077-1082.

Rieder, R., et al. (2004), Chemistry of rocks and soils at Meridiani Planum from the Alpha Particle X-ray Spectrometer, Science, 306, 1746-1749.

Rodriguez, J. A., P. S. Saski, R. O. Kuzmin, J. M. Dohm, K. L. Tanaka, H. Miyamoto, K. Kurita, G. Komatsu, A. G. Fairén, and J. C. Ferris (2005a), Outflow channel sources, reactivation, and chaos formation, Xanthe Terra, Mars, Icarus, 175, 36-57.

Rodriguez, J., et al. (2005b), Control of impact crater fracture systems on subsurface hydrology, ground subsidence, and collapse, Mars, J. Geophys. Res., 110, E06003, doi:10.1029/2004JE002365.

Rosing, M. T. (1999), ${ }^{13}$ C-depleted carbon microparticles in $>3700$-Ma seafloor sedimentary rocks from west Greenland, Science, 283, 674-676.

Rouxel, O. J., A. Bekker, and K. J. Edwards (2005), Iron isotope constraints on the Archean and Paleoproterozoic ocean redox state, Science, 307, $1088-1091$.

Runnegar, B. N. (1992a), Proterozoic fossils of soft-bodied metazoans (Ediacaran faunas), in The Proterozoic Biosphere, edited by J. W. Schopf and C. Klein, pp. 999-1007, Cambridge Univ. Press, New York.

Runnegar, B. N. (1992b), Evolution of the earliest animals, in Major Events in the History of Life, edited by J. W. Schopf, pp. 65-93, Jones and Bartlett, Boston, Mass.

Sagan, C., and C. Chyba (1997), The early faint sun paradox: Organic shielding ofultraviolet-labile greenhouse gases, Science, 276, $1217-$ 1221.

Satterfield, C. L., T. K. Lowenstein, R. H. Vreeland, W. D. Rosenzweig, and D. W. Powers (2005), New evidence for 250 Ma age of halotolerant bacterium from a Permian salt crystal, Geology, 33, 265-268.

Schopf, J. W. (1992), The paleobiology of the Archean, in The ProterozoicBiosphere: A Multidisciplinary Study, edited by J. W. Schopf and C. Klein, pp. 25-42, Cambridge Univ. Press, New York. 
Schopf, J. W. (1993), Microfossils of the early Archean Apex Chert: New evidence of the antiquity of life, Science, 260, 640-645.

Schopf, J. W., and B. M. Packer (1987), Early Archean (3.3 billion to 3.5 billion-year-old) microfossils from Warrawoona Group, Australia, Science, 237, 70-73.

Schubert, G., S. C. Solomon, D. L. Turcotte, M. J. Drake, and N. H. Sleep (1992), Origin and thermal evolution of Mars, in Mars, edited by H. H. Kieffer et al., pp. 147-183, Univ. of Ariz. Press, Tucson.

Schulze-Makuch, D., and D. H. Grinspoon (2005), Biologically enhanced energy and carbon cycling on Titan?, Astrobiology, 5, 560-567.

Schulze-Makuch, D., and L. N. Irwin (2002), Energy cycling and hypothetical organisms in Europa's ocean, Astrobiology, 2, 105-121.

Schulze-Makuch, D., and L. N. Irwin (2004), Life in the Universe: Expectations and Constraints, Springer, New York

Schulze-Makuch, D., L. N. Irwin, and H. Guan (2002), Search parameters for the remote detection of extraterrestrial life, Planet. Space Sci., 50, $675-683$

Schulze-Makuch, D., D. H. Grinspoon, O. Abbas, L. N. Irwin, and M. Bullock (2004), A sulfur-based UV adaptation strategy for putative phototrophic life in the Venusian atmosphere, Astrobiology, 4, 11-18.

Scott, D. H., and K. L. Tanaka (1986), Geologic map of the western equatorial region of Mars, U.S. Geol. Surv. Misc. Invest. Ser., Map I-1802-A, scale $1: 15,000,000$

Scott, D. H., J. M. Dohm, and J. W. Rice (1995), Map of Mars showing channels and possible paleolake basins, U.S. Geol. Surv. Misc. Invest. Ser., Map I-2461.

Segura, T. L., O. B. Toon, A. Colaprete, and K. Zahnle (2002), Environmental effects of large impacts on Mars, Science, 298, 1977-1980.

Shuster, D. L., and B. P. Weiss (2005), Martian surface paleotemperatures from thermochronology of meteorites, Science, 309, 594-600.

Simonson, B. M., and K. E. Carney (1999), Roll-up structures: Evidence of in situ microbial mats in late Archean deep shelf environments, Palaios, 14(1), 13-24.

Sleep, N. H. (1994), Martian plate tectonics, J. Geophys. Res., 99(E3), $5639-5656$

Solomon, S. C., et al. (2005), New perspectives on ancient Mars, Science, $307,1214-1220$

Squyres, S. W., and J. F. Kasting (1994), Early Mars: How warm and how wet?, Science, 265, 744-749.

Squyres, S. W., D. E. Wilhelms, and A. C. Moosman (1987), Large-scale volcano-ground ice interactions on Mars, Icarus, 70(3), 385-408.

Squyres, S. W., et al. (2004), In situ evidence for an ancient aqueous environment at Meridiani Planum, Mars, Science, 306, 1709-1714.

Stevens, T. O., and J. P. McKinley (1995), Lithoautotrophic microbial ecosystems in deep basalt aquifers, Science, 270, 450-454.

Strom, R. G., R. Malhotra, T. Ito, F. Yoshida, and D. A. Kring (2005), The origin of planetary impactors in the inner solar system, Science, 309 , $1847-1850$

Summons, R. E., L. L. Jahnke, J. M. Hope, and G. A. Logan (1999), 2-methylhopanoids as biomarkers for cyanobacteria oxygenic photosynthesis, Nature, 400, 554-557.
Tanaka, K. L., J. M. Dohm, J. H. Lias, and T. M. Hare (1998), Erosional valleys in the Thaumasia region of Mars: Hydrothermal and seismic origins, J. Geophys. Res., 103, 31,407-31,419.

Torsvik, V., L. Ovreas, and T. F. Thingstad (2002), Prokaryotic diversityMagnitude, dynamics, and controlling factors, Science, 296(5570), $1064-1066$

Touma, J., and J. Wisdom (1993), The chaotic obliquity of Mars, Science, $259,1294-1296$

Tsiganis, K., R. Gomes, A. Morbidelli, and H. F. Levison (2005), Origin of the orbital architecture of the giant planets of the solar system, Nature, $435,459-461$.

Valentine, J. W. (2002), Prelude to the Cambrian explosion, Annu. Rev. Earth Planet. Sci., 30, 285-306.

Valentine, J. W. (2004), On the Origin of Phyla, 614 pp., Univ. of Chicago Press, Chicago, Ill.

Valentine, J. W., S. M. Awramik, P. W. Signor, and P. M. Sadler (1991), The biological explosion at the Precambrian-Cambrian boundary, Evol. Biol., $25,279-355$.

Vargas, M., K. Kashefi, E. L. Blunt-Harris, and D. R. Lovly (1998), Microbiological evidence for Fe(III) reduction on early Earth, Nature, 395, 6567.

Vidal, G., and M. Moczydlowska-Vidal (1997), Biodiversity, speciation, and extinction trends of Proterozoic and Cambrian phytoplankton, $\mathrm{Pa}$ leobiology, 23(2), 230-246.

Waggoner, B. M. (1995), Ediacaran lichens-A critique, Paleobiology, 2l(3), 393-397

Westall, F. (2005), Early life on Earth and analogies to Mars, in Water on Mars and Life, edited by T. Tokano, pp. 45-64, Springer, New York.

Wilhelms, D. E., and R. J. Baldwin (1989), The role of igneous sills in shaping the Martian uplands, in 19th Lunar and Planetary Science Conference Proceedings, Houston, Texas, March 14-18, 1988, pp. 355-365, Cambridge Univ. Press, New York.

J. M. Dohm, Department of Hydrology and Water Resources, University of Arizona, Tucson, AZ 85721, USA.

A. G. Fairén, Centro de Biología Molecular, Universidad Autónoma de Madrid, E-28049 Cantoblanco, Madrid, Spain.

L. N. Irwin, Department of Biological Sciences, University of Texas at El Paso, El Paso, TX 79968, USA

D. LeMone, Department of Geological Sciences, University of Texas at El Paso, El Paso, TX 79968, USA.

J. H. Lipps, Department of Integrative Biology and Museum of Paleontology, University of California at Berkeley, Berkeley, CA 94720, USA.

D. Schulze-Makuch, Department of Geology, Washington State University, Pullman, WA 99164, USA. (dirksm@wsu.edu) 